\title{
Kajian Rumput Vetiver Sebagai Pengaman Lereng Secara Berkelanjutan
}

\author{
Susilawati \\ Program Studi Teknik Sipil, Universitas Flores, \\ Jl. Sam Ratulangi, Ende \\ E-mail: sr.susi.dp@gmail.com \\ Veronika \\ Program Studi Teknik Sipil, Universitas Flores, \\ Jl. Sam Ratulangi, Ende \\ E-mail: veronika_mira@yahoo.com
}

\begin{abstract}
Flores is the island in the NTT province, which has a row of volcanoes, with the mountainous topography. Transportation is state road, along the coast with high cliffs on the other side. That often causes problems during the rainy season as several landslides. Various methods are used to overcome this landslide. Studies on vetiver grass as slope protection done to secure the slopes on a sustainable basis. First, an evaluation done for the slope construction along the slope safety from Nangaroro to Aegela, which are using vetiver grass as a safety slopes in addition to other security structures. It is also done for the same job of the road from Ende to Nangaroro and Ende-Detusoko. This study covers the technical aspects, ecological, construction and sustainability of the infrastructure that has been built. Furthermore, it is done the literature study to find more appropriate method, environmentally friendly and sustainable in securing these slopes problematic. From the literature studies and the field survey done, it can be concluded and recommended several models of eco-friendly structural design of vetiver grass and geotextile for slope protection, which is based on technical-meet standard strength, ecologically-friendly environment, locally-developed local wisdom, so it is easy to construct.
\end{abstract}

Keywords: Slope erosion, Vetiver grass, Ecological, Local wisdom, Sustainable.

\begin{abstract}
Abstrak
Flores merupakan salah satu pulau dalam wilayah Provinsi NTT, yang memiliki deretan gunung berapi, dengan topografi pegunungan. Transportasi darat yang merupakan jalan negara, menyusuri pantai dengan tebing tinggi di sisi lainnya, sering menimbulkan masalah saat musim hujan, yaitu banyaknya lereng yang longsor. Berbagai cara dilakukan untuk mengatasi longsor ini. Kajian rumput vetiver sebagai pengaman lereng dilakukan sebagai salah satu cara untuk mengamankan lereng secara berkelanjutan. Pertama-tama dilakukan evaluasi atas pekerjaan pengaman lereng sepanjang Jalan Nangaroro-Aegela yang menggunakan rumput vetiver sebagai pengaman lereng selain struktur pengaman lainnya, dengan pekerjaan yang sama untuk jalan antara Ende-Nangaroro dan Ende-Detusoko. Kajian ini meliputi aspek teknis, ekologis, proses konstruksi dan keberlanjutan dari infrastruktur yang telah dibangun. Selanjutnya, dilakukan studi pustaka untuk menemukan metode yang lebih tepat, ramah lingkungan dan berkelanjutan dalam mengamankan lereng bermasalah ini. Dari kajian dan studi pustaka yang telah dilakukan, dapat disimpulkan serta direkomendasikan beberapa model desain struktur ramah lingkungan dengan rumput vetiver dan geotekstil sebagai pengaman lereng secara berkelanjutan. Model desain yang direkomendasikan didasarkan pada pertimbangan beberapa aspek: teknis-memenuhi strandar kekuatan, ekologis-ramah lingkungan, kearifan lokal-dikembangkan dari apa yang telah dilakukan oleh masyarakat, sehingga mudah dikerjakan dengan proses yang ramah lingkungan dan sistem berkelanjutan.
\end{abstract}

Kata-kata Kunci: Lereng longsor, Rumput vetiver, Ekologis, Kearifan lokal, Berkelanjutan. 


\section{Pendahuluan}

Flores merupakan salah satu pulau dalam wilayah Provinsi NTT, yang memiliki deretan gunung berapi, dengan topografi pegunungan (Gambar 1). Transportasi darat yang merupakan jalan negara, menyusuri pantai dengan tebing tinggi di sisi lainnya, sering menimbulkan masalah saat musim hujan, yaitu banyaknya lereng yang longsor.

Sumber dari ESDM menyebutkan adanya 6 jenis lereng longsor, yang sering menjadi acuan dalam menganalisa bencana tanah longsor yang terjadi, yakni:

1. Longsoran translasi, adalah bergeraknya massa tanah dan batuan pada bidang gelincir berbentuk rata atau menggelombang landai (Gambar 2).

2. Longsoran rotasi, yaitu bergeraknya massa tanah dan batuan pada bidang gelincir berbentuk cekung (Gambar 3).

3. Pergerakan blok, adalah perpindahan batuan yang bergerak pada bidang gelincir berbentuk rata. Longsoran ini disebut juga longsoran translasi blok batu (Gambar 4).

4. Runtuhan batu, terjadi ketika sejumlah besar batuan atau material lain bergerak ke bawah dengan cara jatuh bebas. Umumnya terjadi pada lereng yang terjal hingga menggantung, terutama di daerah pantai. Batu-batu besar yang jatuh dapat menyebabkan kerusakan yang parah (Gambar 5).

5. Rayapan tanah, adalah jenis tanah longsor yang bergerak lambat. Jenis tanahnya berupa butiran kasar dan halus. Jenis tanah longsor ini hamper tidak dapat dikenali. Setelah waktu yang cukup lama longsor jenis rayapan ini bisa menyebabkan tiang-tiang tilpon, pohon ataupun rumah miring ke bawah (Gambar 6).

6. Aliran bahan rombakan, yang terjadi ketika massa tanah bergerak didorong oleh air. Kecepatan aliran tergantung pada kemiringan lereng, volume dan tekanan air, dan jenis materialnya. Gerakannya terjadi di sepanjang lembah dan mampu mencapai ratusan meter jauhnya. Di beberapa tempat bisa sampai ribuan meter, seperti di daerah aliran sungai, di sekitar gunung api (Gambar 7).

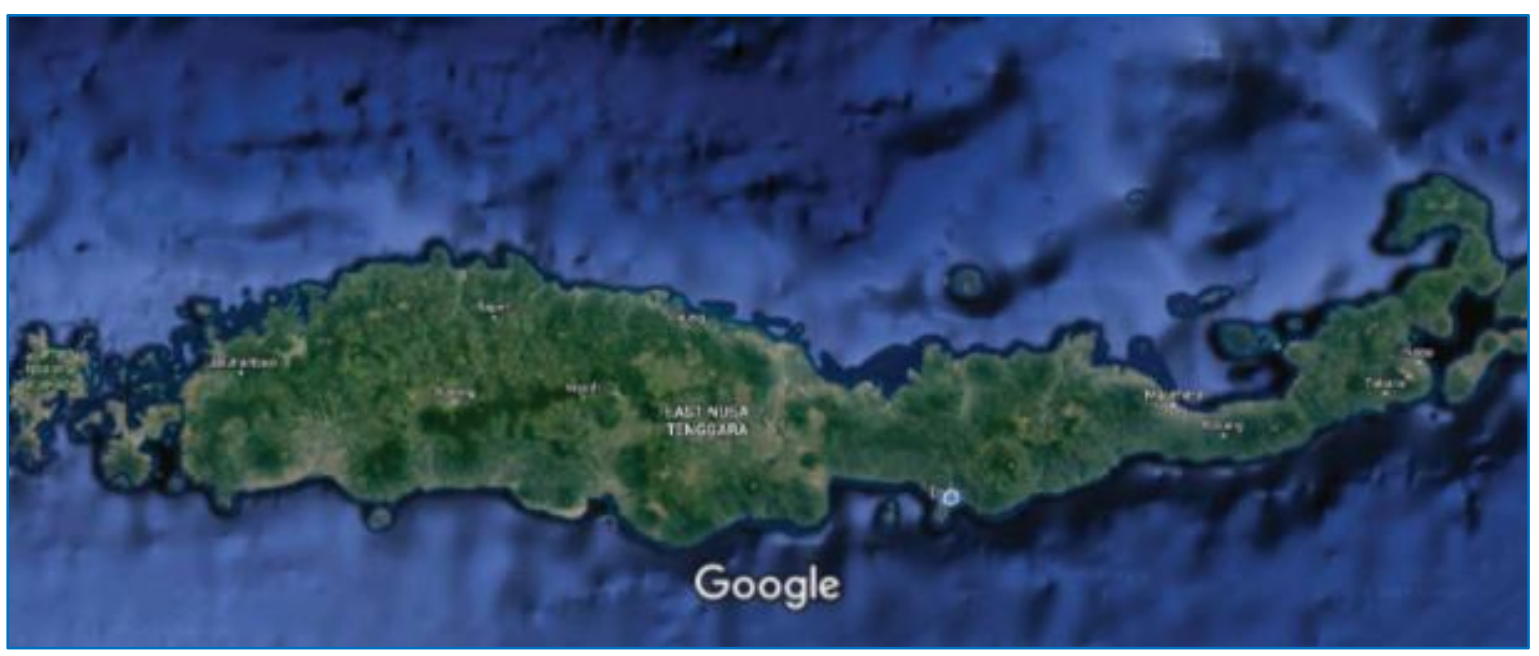

Gambar 1. Daratan Flores dengan sederetan pegunungannya (google map)

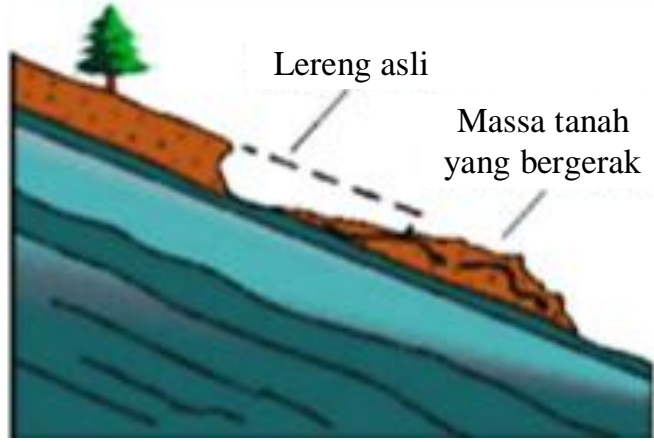

Gambar 2. Longsoran translasi

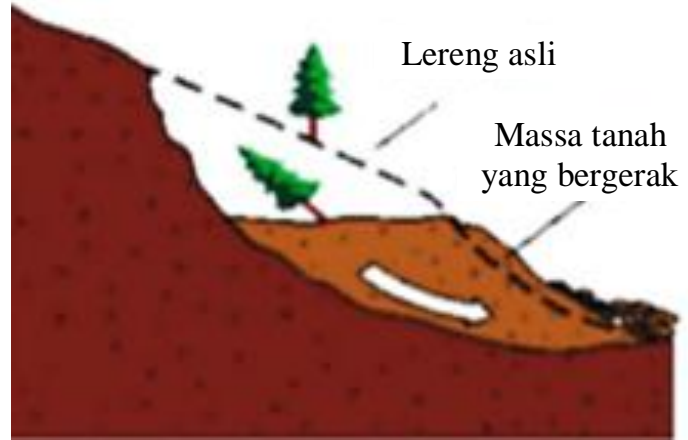

Gambar 3. Longsoran rotasi 


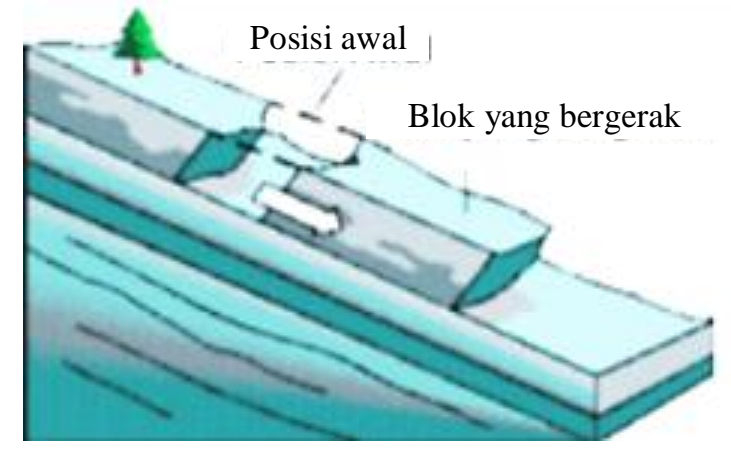

Gambar 4. Pergerakan blok gambar

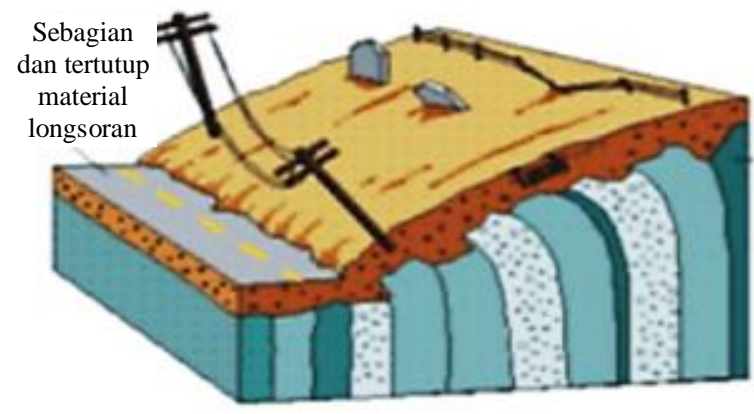

Gambar 6. Rayapan tanah

Lereng longsor terjadi karena adanya gangguan kestabilan pada tanah/batuan penyusun lereng. Penyebab longsoran ini dapat dibedakan antara: a) yang menjadi penyebab longsoran: faktor pengontrol gangguan kestabilan lereng dan b) proses pemicu longsoran. Gangguan kestabilan lereng ini dikontrol oleh: a) kondisi morfologi (terutama kemiringan lereng), b) kondisi batuan ataupun tanah penyusun lereng dan c) kondisi hidrologi atau tata air pada lereng. Meskipun suatu lereng rentan atau berpotensi untuk longsor, karena kondisi kemiringan lereng, batuan/tanah dan tata airnya, namun lereng tersebut belum akan longsor atau terganggu kestabilannya tanpa dipicu oleh proses pemicu longsoran.

Faktor pengontrol gangguan kestabilan lereng:

a. Penggundulan hutan, tanah longsor umumnya banyak terjadi di daerah yang relatif gundul dimana pengikatan air tanah sangat kurang.

b. Batuan endapan gunungapi dan batuan sedimen berukuran pasir dan campuran antara kerikil, pasir, dan lempung umumnya kurang kuat. Batuan ini mudah menjadi tanah bila mengalami proses pelapukan, rentan longsor bila terdapat pada lereng yang terjal.

c. Jenis tanah yang kurang padat adalah tanah lempung atau tanah liat dengan ketebalan lebih dari $2,5 \mathrm{~m}$ dan sudut lereng cukup tinggi memiliki potensi untuk terjadinya tanah longsor terutama bila terjadi hujan. Selain itu tanah ini sangat rentan terhadap pergerakan

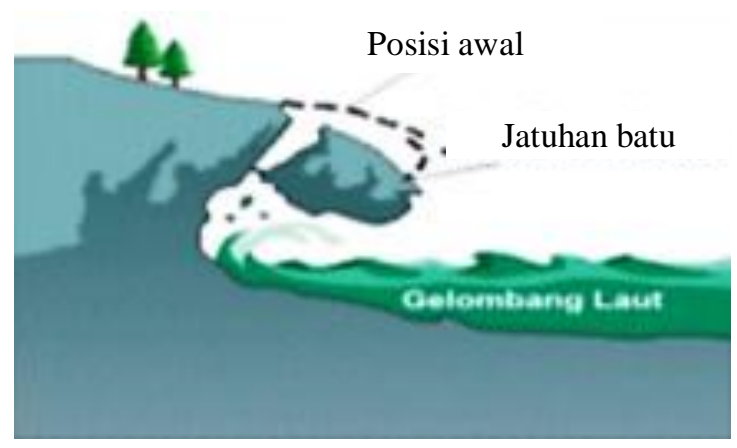

Gambar 5. Runtuhan batu

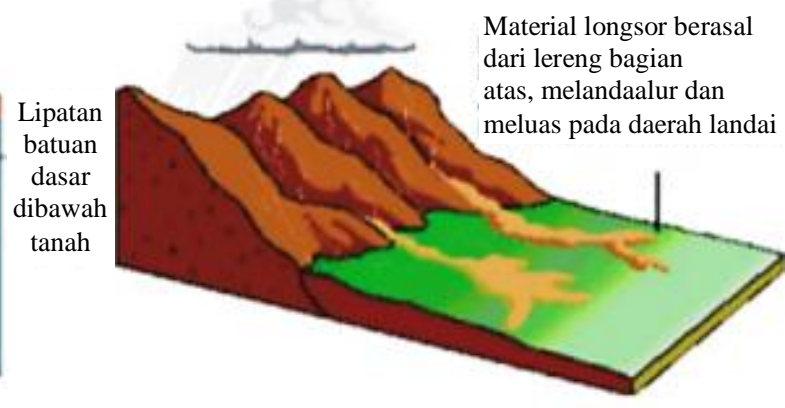

Gambar 7. Aliran bahan rombakan

tanah karena menjadi lembek terkena air dan pecah ketika udara panas.

d. Ancaman tanah longsor dimulai karena meningkatnya intensitas curah hujan. Musim kering yang panjang akan menyebabkan terjadinya penguapan air di permukaan tanah dalam jumlah besar. Hal itu mengakibatkan munculnya pori-pori atau rongga tanah hingga terjadi retakan dan merekahnya tanah permukaan.

e. Lereng atau tebing yang terjal akan memperbesar gaya pendorong. Lereng yang terjal terbentuk karena pengikisan air sungai, mata air, air laut, dan angin.

f. Tanah longsor banyak terjadi di daerah persawahan, perladangan, dan genangan air di lereng yang terjal. Pada lahan persawahan, akarnya kurang kuat untuk mengikat butir tanah, membuat tanah menjadi lembek dan jenuh air, sehingga mudah terjadi longsor. Pada daerah perladangan, akar pohon tidak dapat menembus bidang longsoran yang dalam dan akan terjadi di daerah longsoran lama.

Beberapa pemicu longsoran dapat berupa:

a. Peningkatan kandungan air dalam lereng karena hujan, air kolam/selokan yang bocor atau air sawah ke dalam lereng.

b. Getaran pada lereng akibat gempa bumi ataupun ledakan, penggalian, getaran alat/kendaraan. 
c. Peningkatan beban (bangunan atau pohon terlalu rimbun), yang melampaui daya dukung tanah atau kuat geser tanah.

d. Pemotongan kaki lereng secara sembarangan yang mengakibatkan lereng kehilangan gaya penyangga.

e. Susutnya muka air yang cepat di danau/waduk yang dapat menurunkan gaya penahan lereng, sehingga mudah terjadi longsoran dan penurunan tanah yang biasanya diikuti oleh retakan.

Zulfialdi, dkk. (2013) menyebutkan bahwa daerah rawan longsor bisa terjadi karena kemiringan lereng yang besar, lereng gundul, laju erosi besar, atau infiltrasi besar. Daerah rawan longsor dapat dicegah melalui rekayasa lereng stabil. Rekayasa lereng stabil dapat melalui berbagai cara yang terpadu dengan prosedur dimulai dari:

a. Pemetaan wilayah rawan longsor,

b. Analisis kestabilan lereng melalui kajian Faktor Keamanan Lereng,

c. Stabilisasi dan rancangbangun lereng terpadu melalui simulasi lereng stabil, desain lereng dan rekayasa lainnya,

d. Pengelolaan lingkungan dan monitoring lingkungan,

e. Bio-engineering dengan memanfaatkan tanaman sebagai bagian dari sistem rekayasa lereng stabil, yaitu sebagai agen pencegahan erosi, pengurangan infiltrasi dan alir limpasan, pencegah longsor sekaligus sebagai perkuatan lereng.

Rekayasa dapat menggunakan model Starlet (stabilisasi dan rancang bangun lereng terpadu) yang melibatkan peran aparat pemerintahan, pengusaha, penduduk/masyarakat, dan ilmuwan. Kaliandra dipilih menjadi tanaman yang merupakan bagian sebagai rekayasa lereng stabil. Tanaman Kaliandra mempunyai perakaran yang baik, tajuk pohon tidak berat, daun berprotein tinggi untuk pakan ternak, batang dan ranting yang kering untuk energi (kayu bakar). Tanaman ini, selain pencegah longsor, akan berguna bagi masyarakat maupun industri.

Rumput vetiver mempunyai bentuk fisik dengan tinggi antara 1,5-2,5 m, perakarannya dalam dan massif, mampu masuk sangat jauh ke dalam tanah. Bahkan ada yang mampu menembus hingga kedalaman 5,2 meter (Gambar 8). Bila ditanam di lereng-lereng keras dan berbatu, ujung-ujung akar vetiver mampu masuk menembus dan menjadi semacam jangkar yang kuat. Cara kerja akar ini seperti besi kolom yang masuk ke dalam menembus lapisan tanah, dan pada saat yang sama menahan partikel-partikel tanah dengan akar serabutnya. Kondisi seperti ini dapat mencegah erosi yang disebabkan oleh angin dan air sehingga vetiver dijuluki sebagai "kolom hidup". Batangnya kaku dan keras, tahan terhadap aliran air dalam (0,6 - 0,8 m), jika ditanam berdekatan, membentuk baris/pagar yang rapat. Hal ini akan mengurangi kecepatan aliran, mengalihkan air larian dan dapat menjadi filter yang sangat efektif. Rumput ini tidak menghasilkan bunga dan biji yang dapat menyebar liar seperti alang-alang atau rerumputan lainnya.

Keunggulan vetiver, antara lain: tahan terhadap variasi cuaca, seperti: kekeringan panjang, banjir, genangan dan temperatur $-14^{\circ} \mathrm{C}$ sampai $55^{\circ} \mathrm{C}$; mempunyai daya adaptasi pertumbuhan yang sangat luas pada berbagai kondisi tanah, seperti: pada tanah masam (mengandung mangan dan aluminium), tanah bersalinitas tinggi dan mengandung banyak natrium, tanah yang mengandung logam berat, seperti: $\mathrm{Ar}, \mathrm{Cd}, \mathrm{Co}, \mathrm{Cr}$, $\mathrm{Pb}, \mathrm{Hg}, \mathrm{Ni}$, Se dan $\mathrm{Zn}$, rentang $\mathrm{pH}$ tanah: 3-10,5; mampu menembus lapisan keras hingga kedalaman $15 \mathrm{~cm}$, sehingga dapat bekerja sebagai paku tanah atau pasak yang hidup; sangat praktis, tidak mahal, mudah dipelihara, dan sangat efektif dalam mengontrol erosi dan sedimentasi tanah, konservasi air, serta stabilisasi dan rehabilitasi lahan.
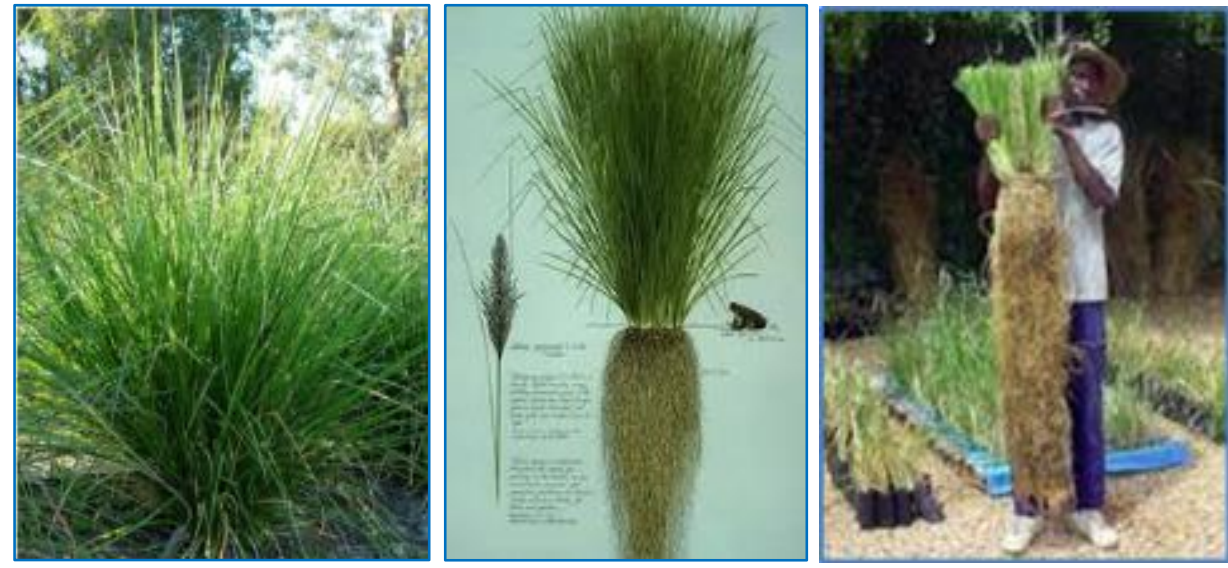

Gambar 8. Bentuk fisik rumput vetiver 
Kelemahan vetiver, antara lain: karena pola pertumbuhan vetiver yang tegak lurus atau vertikal terhadap tanah, maka disarankan penanamannya dikombinasikan dengan jenis tanaman penutup tanah, seperti bahia, rumput pahit (carpet grass) atau jenis kacang-kacangan (legume). Tanaman penutup tanah tersebut dimaksudkan untuk dapat mengurangi percikan dan aliran permukaan terutama pada awal pertumbuhan vetiver. Pada bagian depan, terlihat rumput Bahia menutupi permukaan tanah, sebelum tunas vetiver tumbuh merapat dan daunnya rimbun. Vetiver adalah tanaman hidup, sehingga tidak dapat langsung berfungsi dengan baik dalam menangani erosi permukaan.

Penutupan tanah dengan rumput vetiver minimal $60 \%$, dapat mengurangi tingkat erosi sebesar $90 \%$ (Sunandar \& Kusminingrum, 2010). Penanaman rumput vetiver sepanjang kontur dapat sebagai penghalang untuk pergerakan air dan erosi yang membawa material tanah. Rumput vetiver memiliki kekuatan akar untuk menahan air limpasan deras (Mickovski et al., 2007). Di Jepang, pengaruh penguatan akar pada stabilitas lereng telah diteliti melalui studi empiris dengan mempertimbangkan efek longsor pada penguatan akar. Dalam studi kasus perkuatan lereng, perhitungan menunjukkan bahwa FS meningkat hingga $6,8 \%$ melalui pengaruh penguatan akar pohon. Lereng tetap stabil meskipun air tanah meningkat hingga $0,5 \mathrm{~m}$. Dalam studi yang dilakukan oleh Nakamura et al., (2007), sebuah lereng tanpa perkuatan akar akan menjadi tidak stabil ketika tingkat air tanah bertambah hanya $0,15 \mathrm{~m}$.
Cara kerja rumput vetiver adalah dengan menahan laju air run-off dan material erosi yang terbawa dengan tubuhnya. Daun dan batang vetiver akan memperlambat aliran endapan yang terbawa runoff dititik A sehingga tertumpuk di titik B. Air akan terus mengalir menuruni lereng $\mathrm{C}$ yang lebih rendah. Akar tanaman (D) akan mengikat tanah di bawah tanaman hingga kedalaman 3 meter dengan membentuk "Tiang" yang rapat dan dalam di dalam tanah, akar-akar ini nantinya akan mencegah terjadinya erosi dan longsor. Pada dasarnya rumput vetiver akan efektif jika ditanam dalam bentuk barisan yang membentuk pagar (Gambar 9).

Macam-macam kegunaan rumput vetiver dijelaskan seperti dalam Gambar 10.

Lereng longsor juga dapat ditangani dengan menggunakan bahan geotextile, yang dijelaskan seperti dalam Gambar 11 .

Dengan mengombinasikan antara bahan geotextile dan rumput vetiver, maka akan dicapai hasil penanganan lereng yang lebih baik dan berkelanjutan. Pada saat rumput vetiver masih memerlukan pemeliharaan yang intensif, sehingga belum dapat berfungsi sebagai penahan lereng, maka bahan geotextile akan menahan lereng longsor dengan baik. Saat bahan geotextile mulai mengalami kerapuhan, maka rumput vetiver sudah siap untuk menggantikan peran sebagai penahan lereng yang kokoh dan berkelanjutan karena sedikit membutuhkan pemeliharaan. Kombinasi perpaduan antara geotextile dan rumput vetiver ini dapat dilihat seperti dalam Gambar 12 .

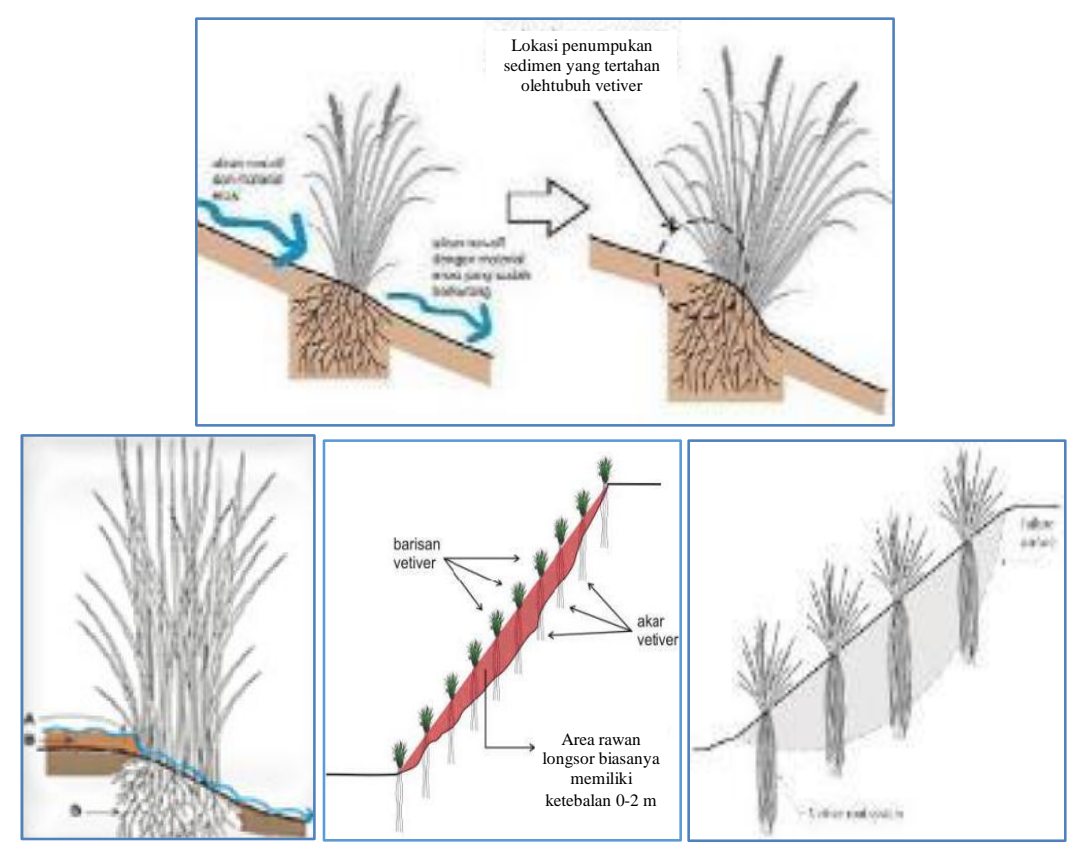

Gambar 9. Cara kerja rumput vetiver (Kadek, 2012; Firmansyah dan Rully, 2011) 

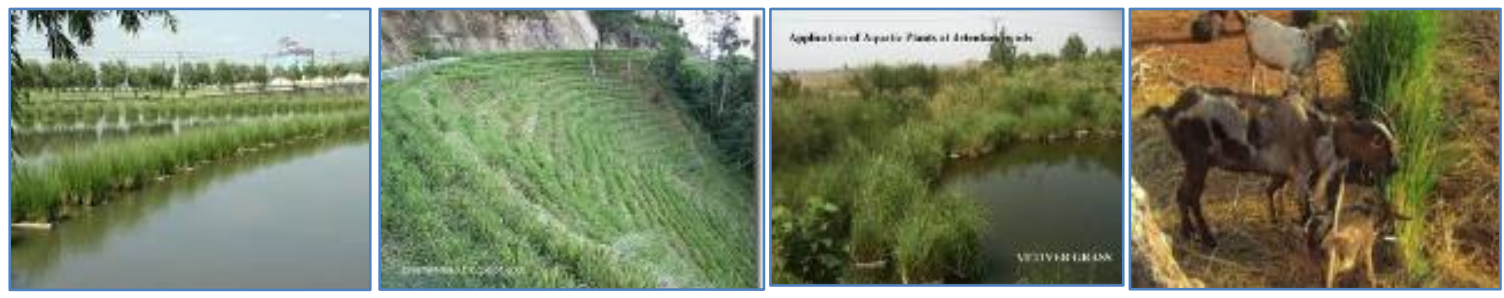

Gambar 10. Macam-macam kegunaan rumput vetiver
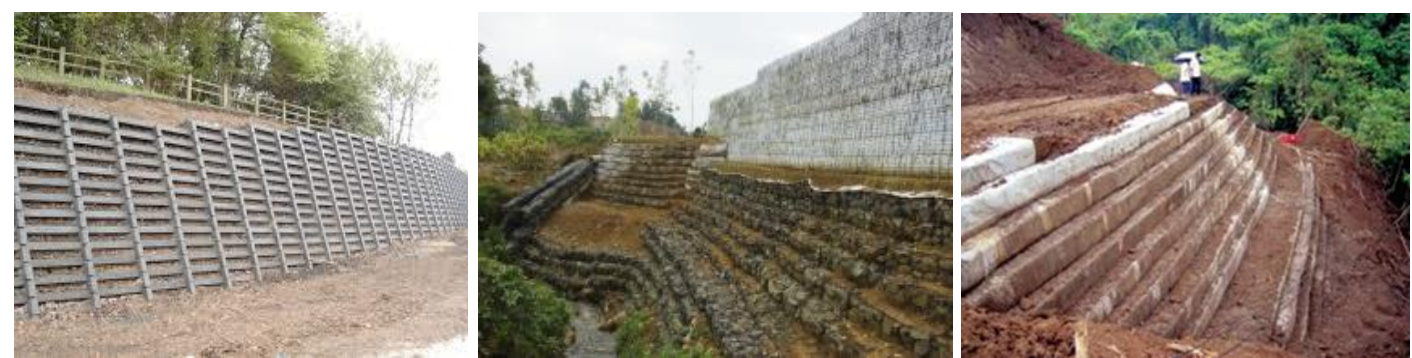

Gambar 11. Penanganan lereng dengan bahan geotextile (geoframe.geoforce-indonesia)
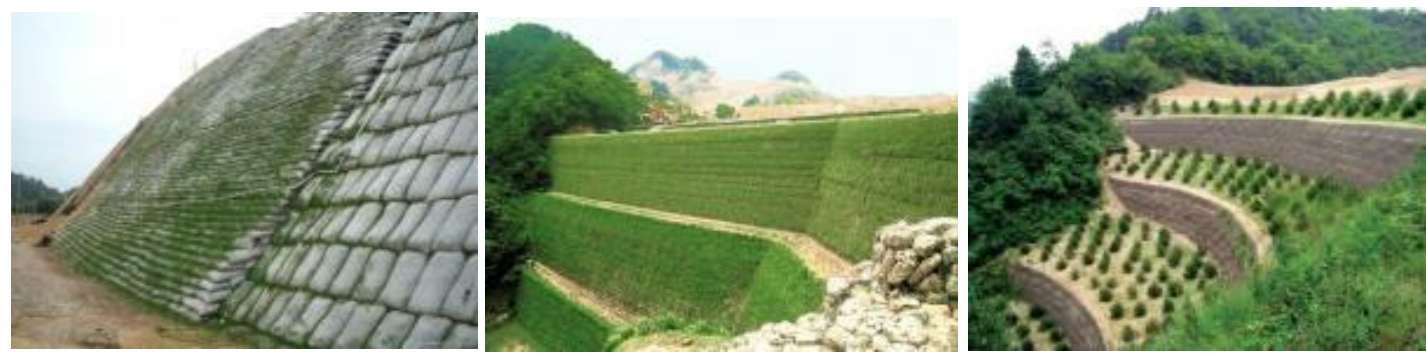

Gambar 12. Kombinasi bahan geotextile dan rumput vetiver

\section{Rumusan masalah}

Pada ruas jalan negara dari Ende sampai Aegela dan dari Ende sampai ke Detusoko, terjadi banyak lereng yang longsor sehingga menimbulkan tertutupnya satu-satunya jalan yang menghubungkan kota-kota di Daratan Flores. Setiap turun hujan, selalu terjadi kelongsoran, sehingga senantiasa ada beberapa alat berat jenis excavator yang selalu siap sedia di lokasi-lokasi rawan longsor.
Berbagai cara dilakukan untuk mengatasi longsor ini, misalnya pada ruas jalan antara Kota Ende dan Aegela, serta ruas jalan antara kota Ende dan Detusoko yang masih dalam proses pengerjaan (Gambar 13).

Yang menjadi permasalahan adalah bagaimana dapat menangani lereng longsor ini secara tepat dan berkelanjutan, sehingga tidak senantiasa terancam akan lereng longsor secara tiba-tiba terlebih pada saat hujan turun.

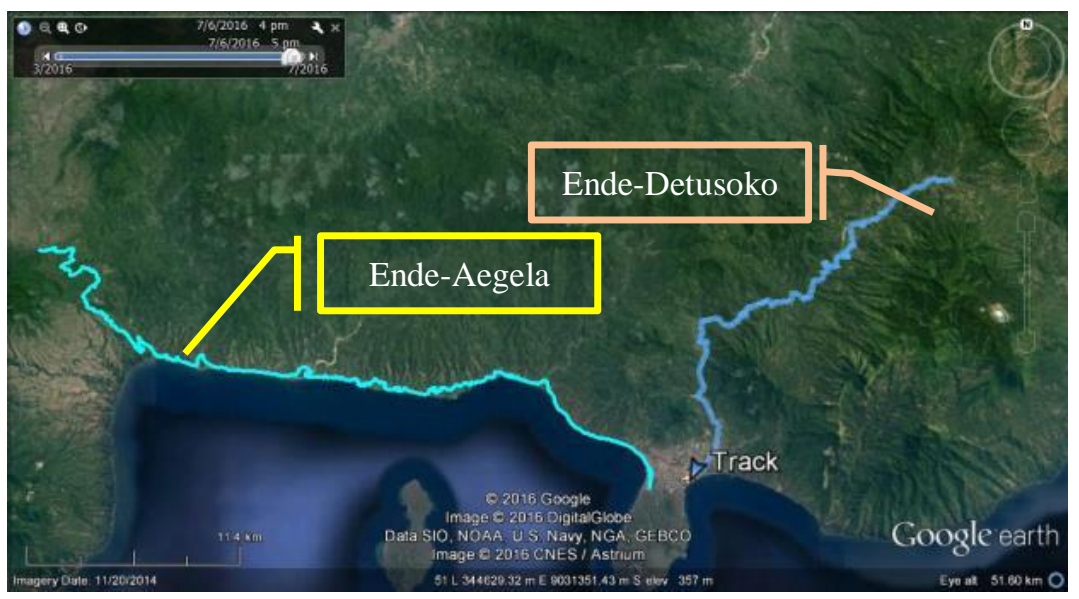

Gambar 13. Route Jalan Ende-Agela dan Ende-Detusoko 


\section{Metodologi Penelitian}

Metode kajian yang dilakukan, pertama-tama adalah melakukan survei ke lokasi route jalan dan mengambil dokumentasi lereng-lereng longsor yang telah ditangani. Kemudian melakukan analisis kajian terhadap apa yang telah diinventaris. Dari kajian ini dapat diberikan catatan-catatan kritis terhadap apa yang telah diupayakan dalam menangani lereng longsor, untuk akhirnya dapat diberikan suatu rekomendasi yang tepat dalam penanganan lereng longsor ini secara ramah lingkungan dan berkelanjutan. Metode kajian ini dapat dijelaskan seperti dalam Gambar 14.

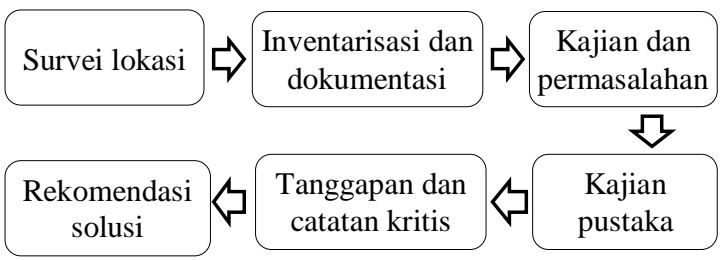

Gambar 14. Diagram metodologi penelitian

\section{Hasil Studi dan Pembahasan}

Penanganan lereng longsor untuk route jalan Ende sampai Aegela, terbagi dalam 2 metode penanganan, yaitu untuk route jalan dari Ende sampai ke Nangaroro yang dikerjakan oleh kontraktor Waskita Karya dilakukan dengan cara memotong bukit-bukit guna memperlebar ruas jalan sehingga diharapkan dapat mengurangi bahaya longsor. Bukit-bukit yang dipotong dengan alat excavator ini dapat dilihat seperti dalam Gambar 15.

Nampak bahwa lereng yang telah dipotong menjadi sangat labil dan mempunyai resiko bencana tanah longsor yang cukut besar. Pada waktu musim hujan dimana intensitas curah hujan tinggi, menyebabkan kandungan air dalam tanah meningkat cepat, sehingga berakibat pada lerenglereng yang longsor. Lereng yang telah dipotong tersebut mempunyai geologi bebatuan yang cukup banyak, sehingga penanganan diperlukan suatu kombinasi antara bahan geotextile dan rumput vetiver.

Penanganan lereng longsor untuk route jalan dari Nangaroro sampai Aegela dikerjakan oleh kontraktor bantuan dari Australian Aid dilakukan dengan cara memotong bukit-bukit guna memperlebar ruas jalan dan tetap menjaga kelerengan aman serta memperkuat lereng dengan rumput vetiver serta perkuatan pasangan batu kali. Hal ini dapat dilihat seperti dalam gambar 16 . Suatu saluran drainase jalan dikonstruksi juga untuk mengalirkan aliran limpasan ke tempat yang aman (Gambar 17).

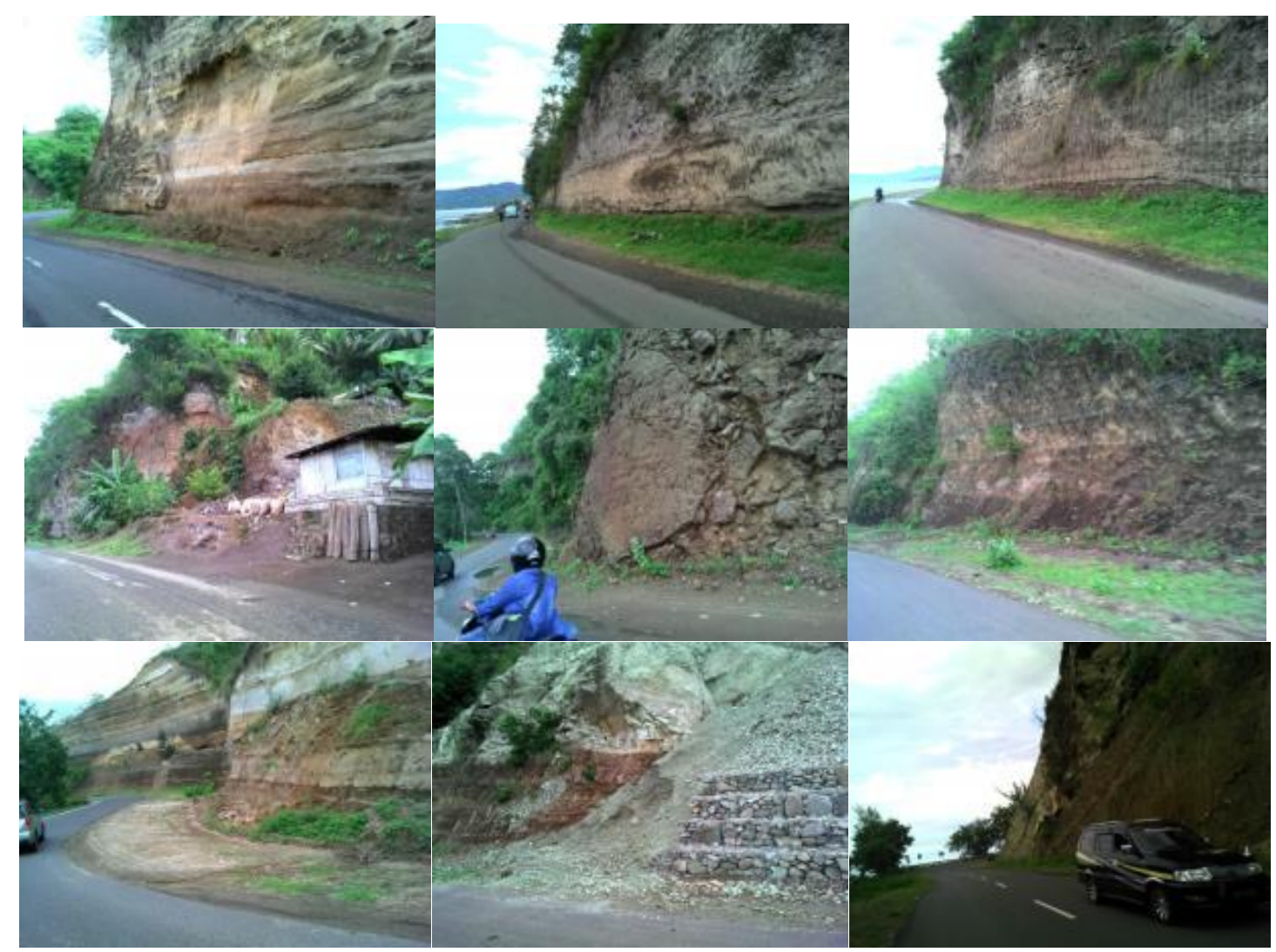

Gambar 15. Pengeprasan lereng dengan excavator 


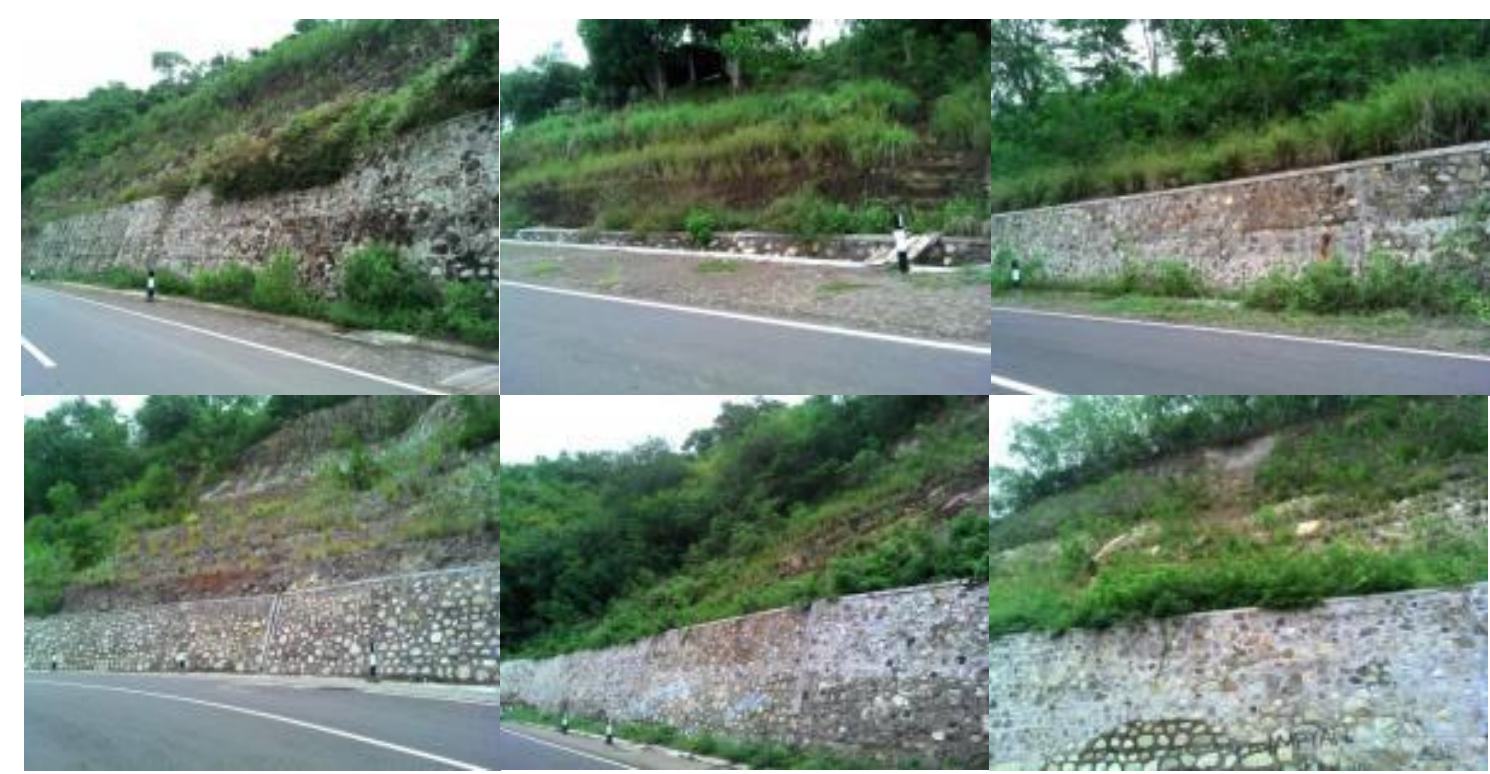

Gambar 16. Perkuatan lereng dengan pasangan batu dan rumput vetiver

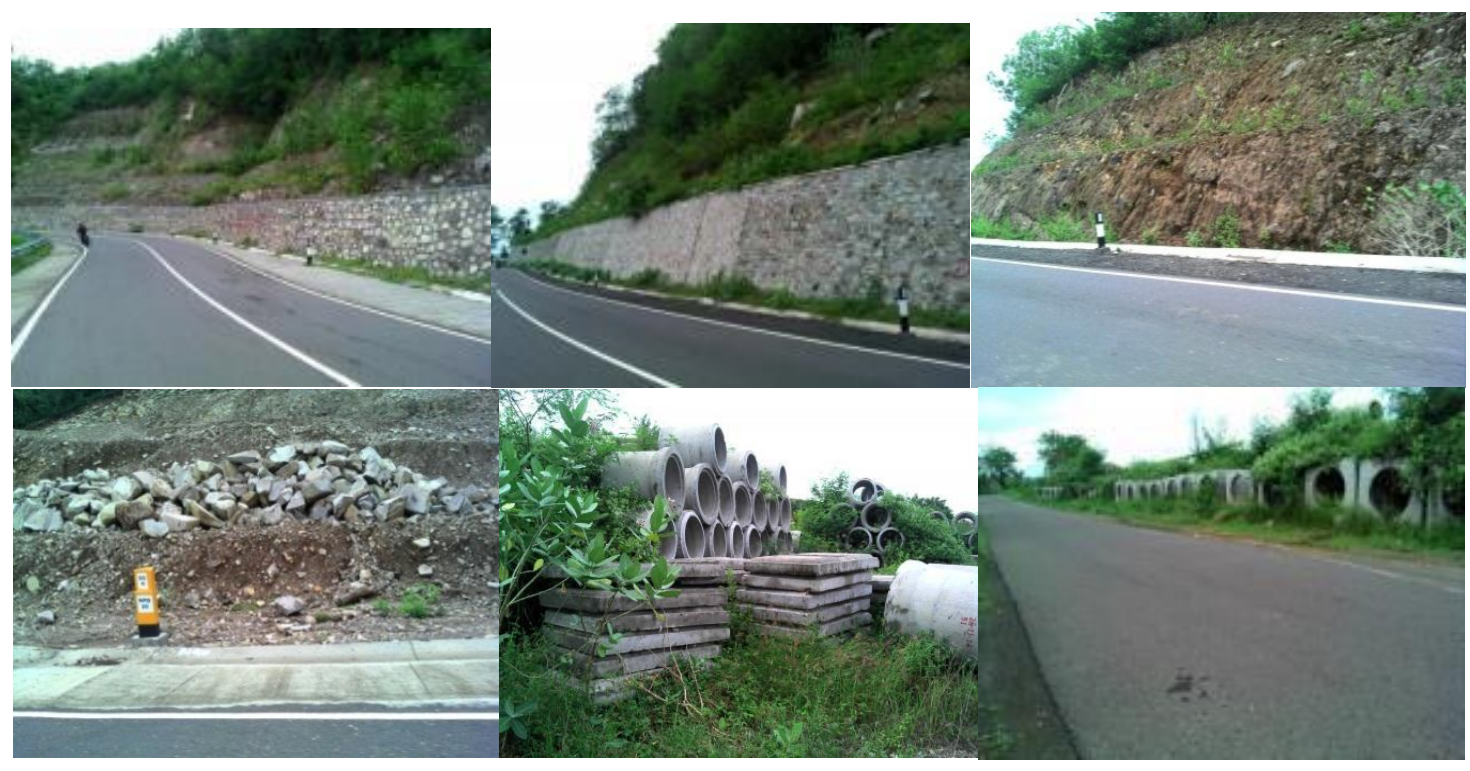

Gambar 17. Drainase jalan untuk mengalirkan air limpasan

Penanganan lereng longsor untuk route jalan dari Ende sampai Detusoko yang masih dalam proses pengerjaan, juga menerapkan metode pengeprasan bukit yang luar biasa sehingga tiap jam kerja maka ruas jalan ditutup, artinya tidak dapat lewat sama sekali, bahkan sepeda motorpun tidak dapat melewatinya. Hal ini dapat dilihat seperti dalam Gambar 18. Pada titik-titik tertentu dibuat perkuatan dengan pasangan batu kali, namun tetap masih terlihat rawan longsor saat hujan turun.

\section{Pembahasan}

Beberapa upaya dalam mengatasi lereng longsor pada ruas Jalan Ende-Detusoko maupun EndeAegela perlu mendapat tanggapan dan catatan kritis, antara lain:
1. Untuk ruas Jalan Ende-Detusoko, beberapa tempat usai pengeprasan bukit, nampak semakin rawan dan tidak stabil karena telah dikepras dengan alat berat. Selama proses konstruksi, banyak gangguan yang ditimbulkan terutama terkait transportasi Maumere-Ende-Ruteng, karena ruas jalan ditutup total selama jam kerja. Lereng yang nampak lebih rawan tersebut, perlu mendapat penanganan yang lebih serius, misalnya dengan memperkenalkan kajian rumput vetiver yang dipadukan dengan geotextile. Geotextile ini berfungsi untuk mengamankan lereng yang rawan longsor.

2. Untuk ruas Jalan Ende-Nangaroro, yang telah usai pengerjaannya, yaitu dengan cara 
mengepras bukit lereng terjal, sehingga nampak mengkhawatirkan dan senantiasa dalam sikap siaga bencana tanah longsor.

3. Untuk ruas Jalan Nangaroro-Aegela, penanganan cukup rapi dan aman. Perlu diberikan catatan terkait dengan rumput vetiver, yang banyak mati karena kurangnya pemeliharaan.

4. Kombinasi atau paduan antara bahan geotextile dan rumput vetiver, merupakan peluang yang sangat potensial memberikan solusi, dengan beberapa catatan untuk menjaga keberlanjutan dari sistem yang diterapkan ini.
Rekomendasi desain dapat diberikan, yang didasarkan pada pertimbangan aspek: teknis yang tetap memenuhi standar kekuatan, ekologis-ramah lingkungan, kearifan lokal dengan desain struktur yang sederhana saja sehingga dapat dilakukan oleh masyarakat sendiri. Pada awal konstruksi, bahan geotextile berfungsi menahan lereng longsor secara kuat, sementara rumput vetiver masih memerlukan pemeliharaan awal yang cukut intensif sampai bertumbuh kuat dan siap menggantikan peran geotextile yang dalam waktu tertentu mulai rusak oleh pengaruh cuaca dan beban. Dasar desain dan cara penanaman rumput vetiver ini ditunjukkan dalam Gambar 19.

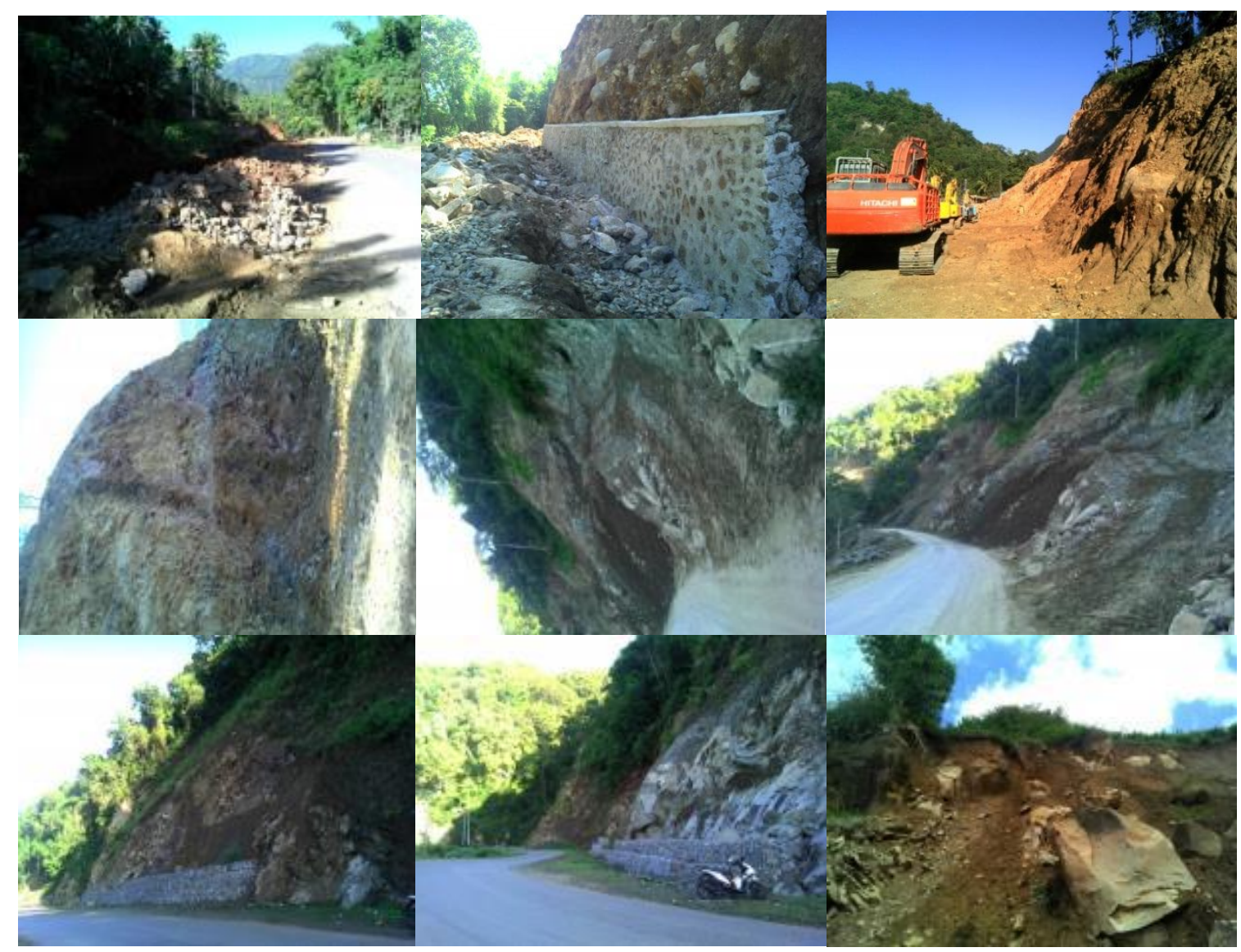

Gambar 18. Pengerjaan lereng longsor pada ruas Jalan Ende sampai Detusoko

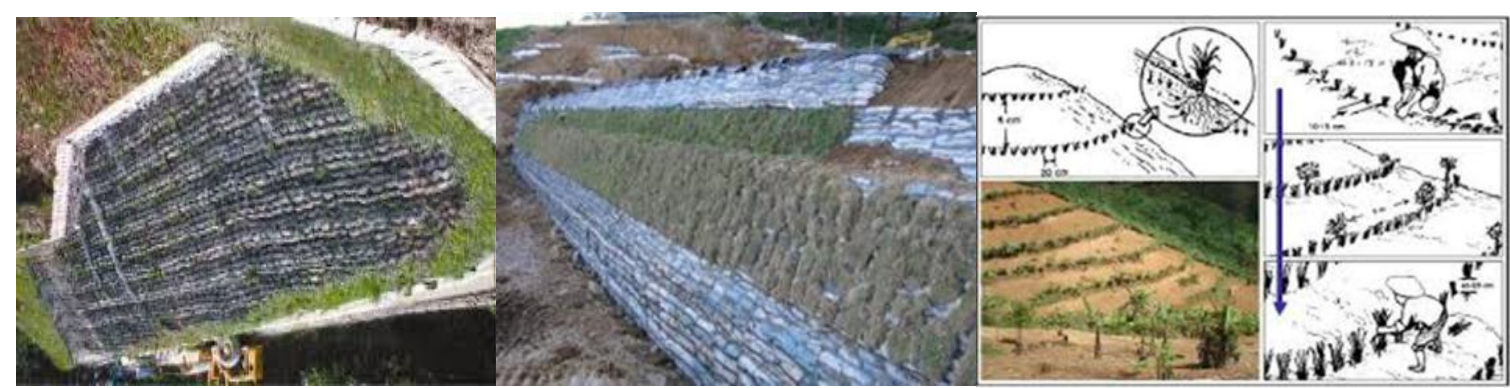

Gambar 19. Penanaman sistem rumput vetiver pada suatu lereng 


\section{Kesimpulan}

Dari kajian dan studi pustaka yang telah dilakukan, dapat disimpulkan serta direkomendasikan beberapa model desain struktur ramah lingkungan dengan rumput vetiver sebagai pengaman lereng secara berkelanjutan. Model desain yang direkomendasikan didasarkan pada pertimbangan beberapa aspek: teknis-memenuhi strandar kekuatan, ekologis-ramah lingkungan, kearifan lokal-dikembangkan dari apa yang telah dilakukan oleh masyarakat, sehingga mudah dikerjakan dengan proses yang ramah lingkungan dan sistem berkelanjutan. Rumput vetiver yang memiliki akar serabut kuat memegang tanah, setelah mengalami pemeliharaan awal yang baik, akan hidup kokoh dan mampu menahan beban tanah yang hendak longsor.

\section{Daftar Pustaka}

ESDM. Diakses dari:

http://www.esdm.go.id/batubara/doc_download/48 9-pengenalan-gerakan-tanah.html.

Firmansam dan Rully, 2011. Pendekatan Biotik dalam Penguatan Lereng. E-Journal Universitas Bandung Raya, Edisi 143, Tahun 2011. Diakses Mei 2014. http://www.e-

journal.unbar.ac.id/detail.php?detail=dosen $\& i d=$ 455.

Geoframe-geoforce.

http://www.geoframe.geoforce-

indonesia.com/geoframe-vimala-hills.html

Kadek, 2012. Teknologi Rumput Vetiver. Diakses pada Juni 2016, dari: http://vetiverindonesia.files.wordpress.com/2012/0 1/teknologi_-rumput_-veritver.pdf .

Mickovski, S. B, Van Beek, LP.H., \& Salin, F., 2007. Uprooting Resist-ance of Vetiver Grass (Vetiveria zizanioides), dalam Eco- and Ground Bio-Engineering, The Use of Vegetation to Improve Slope Stability (Editors: Stokes, A., Spanos, I., Norris, J.E., \& Camme-rat, E.), Spinger, pages $81-90$

Nakamura, H., Nghiem, Q.M., \& Iwasa, N., 2007. Reinforcement of tree roots in slope stability: A case study from the Ozawa slope in Iwate Prefecture, Japan, dalam Eco and Ground BioEngineering: The Use of Vegetation to Improve Slope Stability (Editors: Stokes, A., Spanos, I., Norris, J.E., \& Cammerat, E.), Spinger, pages 8190.

Sunandar, A., \& Kusminingrum, N, 2010. Teknologi Rumput Vetiver untuk Pengendalian Erosi pada Lereng Jalan Guna Meningkatkan Keselamatan dan Kenyamanan Pengguna Jalan, Proseding Kolokium Jalan dan Jembatan, Pusat Penelitian dan Pengembangan Jalan dan Jembatan, Badan Penelitian dan Pengembangan, Kementerian Pekerjaan Umum, hal. 1-18.

Zulfialdi, dkk., 2013. Bio-Engineering, Melalui Pemanfaatan Tanaman Kaliandra (caliandra calothyrsus) di Wilayah Zona Rawan Longsor Jawa Barat, dalam Bulletin of Scientific Contribution, Volume 11, Nomor 3, Desember 2013: 168-175. 